\title{
Analysis of IT Infrastructure Flexibility Impacts on IT-Business Strategic Alignment
}

Yugo Kartono Isal ${ }^{1}$ (D), Gayuh Prima Pikarti ${ }^{1}$ (D) Achmad Nizar Hidayanto ${ }^{1}$ (D), Edson Yahuda Putra ${ }^{2}$

${ }^{1}$ Universitas Indonesia (Indonesia)

${ }^{2}$ Universitas Klabat (Indonesia)

yugo@,cs.ui.ac.id,gayuh.prima@,live.com,nizar@,cs.ui.ac.id, eyabuda@,unklab.ac.id

Received: February 2016

Accepted: June 2016

Abstract:

Purpose: To explore the impacts of IT infrastructure flexibility components (connectivity, modularity, compatibility, and IT personnel flexibility) on IT-business strategic alignment using Luftman's strategic alignment maturity model.

Design/methodology/approach: A questionnaire was developed using 5-points Likert scale. The questionnaire was distributed to companies in Indonesia, where 48 companies filled the questionnaire completely. The data were analyzed using partial least squares (PLS) approach using WarpPLS version 3.0.

Findings: This research found that amongst four components of IT infrastructure flexibility, only compatibility that gives a positive and significant impact to IT-business strategic alignment. This finding is remarkably in contrast to what had been found by Chung et al (2003) in which connectivity, modularity and IT personnel flexibility showed a positive impact on strategic alignment while compatibility did not.

Research limitations: This research used small sample size. More respondents are required to obtain more general conclusions. 
Practical implications: The findings of this study can be input for IT investment initiatives by first focusing on compatibility aspect of IT infrastructure which is considered having the most significant influence on strategic alignment.

Originality/value: Previous study investigated IT infrastructure flexibility as a single concept, whereas our research investigated the components of IT infrastructure flexibility and their impact on strategic alignment.

Keywords: IT infrastructure flexibility, IT-business strategic alignment, Luftman, partial least squares

\section{Introduction}

In recent decades, the role of IT in business has significantly improved - it shifted vastly from cost center into investment center. IT is a valuable asset needed to help organization survive in this fastchanging environment. As the business needs tend to fluctuate in this dynamic setting, a flexible IT infrastructure is a must-to-have so that organization could be more responsive to the change of business demands. However, this requires no small investments. The urgency to provide a flexible - yet cost-efficient IT infrastructure makes IT infrastructure remains an important issue up to nowadays (Alaeddini \& Salekfard, 2013; Gerow, Grover, Thatcher \& Roth, 2014; Patten, Whitworth, Fjermestad \& Mahinda, 2005).

On the other hand, enhancement of the role of IT in business undoubtedly contributed to the increase in IT investment. Unfortunately, not all IT investments successfully deliver business value that is proportional to the amount of investment (Roach, 1991). This failure is believed by Henderson and Venkatraman (1993) motivated by the lack of alignment between business strategy with IT, or popularly as strategic alignment. Strategic alignment itself has been proven to provide value to the company, ranging from improving the effectiveness and performance of the company, increasing competitive advantage, increasing the return on investment and business value-IT and to maintain the stability of the company (Chan, Huff, Barclay \& Copeland, 1997; Charoensuk, Wongsurawat, \& Khang, 2014; Chiang \& Nunez, 2013; Feidler, Gorver \& Teng, 1995; Gerow et al., 2014; Kearns \& Lederer, 2001; Labovitz \& Rosansky, 1997; Orozco, Tarhini, Masa'deh \& Tarhini, 2015; Tallon, Kraemer \& Gurbaxani, 2000; Tarhini, Ammar, Tarhini \& Masa'deh, 2015; Sari, Hidayanto \& Handayani, 2012; Yayla \& Hu, 2012). Considering this, it is no wonder that companies are trying to increase the maturity of its strategic alignment with the hope that the more mature strategic alignment will provide better IT-businesses value. 
However, the strategic alignment in practice is not easy to achieve (Luftman, 1996). Over the last four decades, the strategic alignment remains a top issue faced by executives (Henderson \& Venkatraman, 1993; Kempaiah, 2008). Luftman (1996) argues, strategic alignment will always have its own urgency for IT is still involved in the business. One of the biggest challenges that must be faced in aligning business strategy with IT is a change, be it changes in terms of business strategy, customer demand, as well as changes in prices (Luftman, Papp \& Brier, 1999; Mendelson \& Pillai, 1998). This is where the flexibility of the IT infrastructure needed to answer this challenge. Duncan (1995) even stated that the alignment of business strategy with IT only reached if the company already has a flexible IT infrastructure.

Although the influence of IT infrastructure flexibility to strategic alignment has been investigated in a number of literature (Akhtar \& Mittal, 2014; Chung, Rainer Jr. \& Lewis, 2003; Jorfi, Nor, Najjar \& Jorfi, 2011; Tallon \& Kraemer, 2003), the analysis conducted generally model the IT infrastructure flexibility just as first-order variable without any study deeper about how significant the effect that occurs between the components of the IT infrastructure flexibility with aspects of strategic alignment. Not all organizations have the ability to develop a flexible IT infrastructure due to limited resources, budget, and human resources, so it needs to look at which IT infrastructure flexibility components that should be the focus of the organization to achieve strategic alignment. Unfortunately, in-depth research to discuss the issue are limited, so the research question posed in this study is: what is the relationship between the components of IT infrastructure flexibiltity to strategic alignment?. Strategic alignment that will be used in this study refers to the model proposed by Luftman (2000).

The rest of the paper will be organized as follow. Section 2 discusses theoretical background underlying this research which include IT infrastructure flexibility, IT-Business strategic alignment and hypotheses development. Section 3 explains the methodology used in this research, which include data collection procedures and research instruments. Section 4 presents our research results. Section 5 discusses our research result and its implication. Last, we highlight the conclusion of this research.

\section{Literature Review}

\subsection{IT Infrastructure Flexibility}

IT infrastructure is the foundation of IT capability that is shared, standardized, and functioned as a business process enabler (McKay \& Brockway, 1989). While several literatures define IT infrastructure from technical perspective i.e hardware, core applications, communication technologies and data (Earl, 1989; Duncan, 1995), some others view IT infrastructure as a multifacet concept by highlighting the importance of human IT components (i.e skills, expertise, competency, commitment, value, norm, 
knowledge, etc.) as well as the technical components (Henderson \& Venkatraman, 1993; Broadbent, Weill, \& Neo, 1999; Byrd \& Turner, 2000).

In terms of flexibility, IT infrastructure is considered to be flexible if it is able to effectively control the external environment (De Leeuw \& Volberda, 1996), do various tasks, be responsive to change, and can be easily transformed (Gross \& Raymond, 1993). It also can be represented as the degree to which IT resources are shareable and reusable (Duncan, 1995). Based on the concept of reach and range (Keen, 1991), Duncan (1995) defines flexibility in terms of three technical components, namely connectivity, modularity, and compatibility. Connectivity represents IT components ability to communicate with other components, both internally and externally. Modularity is the ability to easily reconfigure (add, modify, or remove) technical IT components with little or no major impact. Compatibility denotes the ability to distribute any type of information across any technology component. In respect to the findings found by Lee, Trauth and Farwell (1995) and Broadbent, Weill, O'Brien and Neo (1996), Byrd and Turner (2000) added IT personnel flexibility as another complementary dimension of IT infrastructure flexibility. According to Masrek and Jusoff (2009), IT personnel flexibility represents the ability of IT personnel in dealing with changes in business needs and to work cooperatively across functional units by using various technology platforms. Those four components (connectivity, modularity, compatibility and IT personnel flexibility) are adopted in this study to provide a comprehensive view on IT infrastructure flexibility.

The importance of IT infrastructure flexibility has been emphasized on previous studies. Allen and Boynton (1991) argue that efficiency and flexibility are two important factors for IT systems. IT infrastructure requires to be flexible so that customer demands could be well-handled without any additional costs (Weill, 1993). In addition, flexibility is a parameter of IT infrastructure effectiveness and should be viewed as corporate core competence (Davenport \& Linder, 1994). In a similar vein, Henderson and Venkatraman (1993) suggested flexibility and the pace of IT implementation as the main focus of IT infrastructure.

\subsection{IT-Business Strategic Alignment}

The concept of IT-business strategic alignment has been around since the 1980s and becomes corporate main concern in the 1990s (Brancheau, Janz \& Wetherbe, 1996; Plowman, 1998). It is etymologically formed from the term "strategy" and "alignment". "Strategy" is defined either as formulation and implementation (Henderson \& Venkatraman, 1993), plan (Teo \& King, 1997), or objective (Reich \& Benbasat, 1996), while "alignment" is coordination achieved when information systems strategy is derived from corporate strategy (Lederer \& Mendelow, 1989). Terminologically speaking, IT-business strategic alignment is defined as the degree to which business mission, objectives and plans supported and are 
supported by IT mission, objectives and plans (Reich \& Benbasat, 1996). In a similar vein, Sabherwal and Chan (2001) define strategic alignment as the degree of congruence between business and IT's strategic orientation.

In 1993, Henderson and Venkatraman (1993) proposed Strategic Alignment Model (SAM), a model that can be considered as the founding father in conceptualizing strategic alignment. They believe that strategic alignment is the missing link between IT and business that underlies the failure of IT investments in delivering appropriate business value. SAM has been extensively accepted and validated for its good conceptual and practical values (Avison, Jones, Powell \& Wilson, 2004). As depicted in Figure 1, SAM comprises four domains, namely: business strategy, organizational infrastructure and processes, IT strategy, and IS infrastructure and processes, with each domain consists of three components.

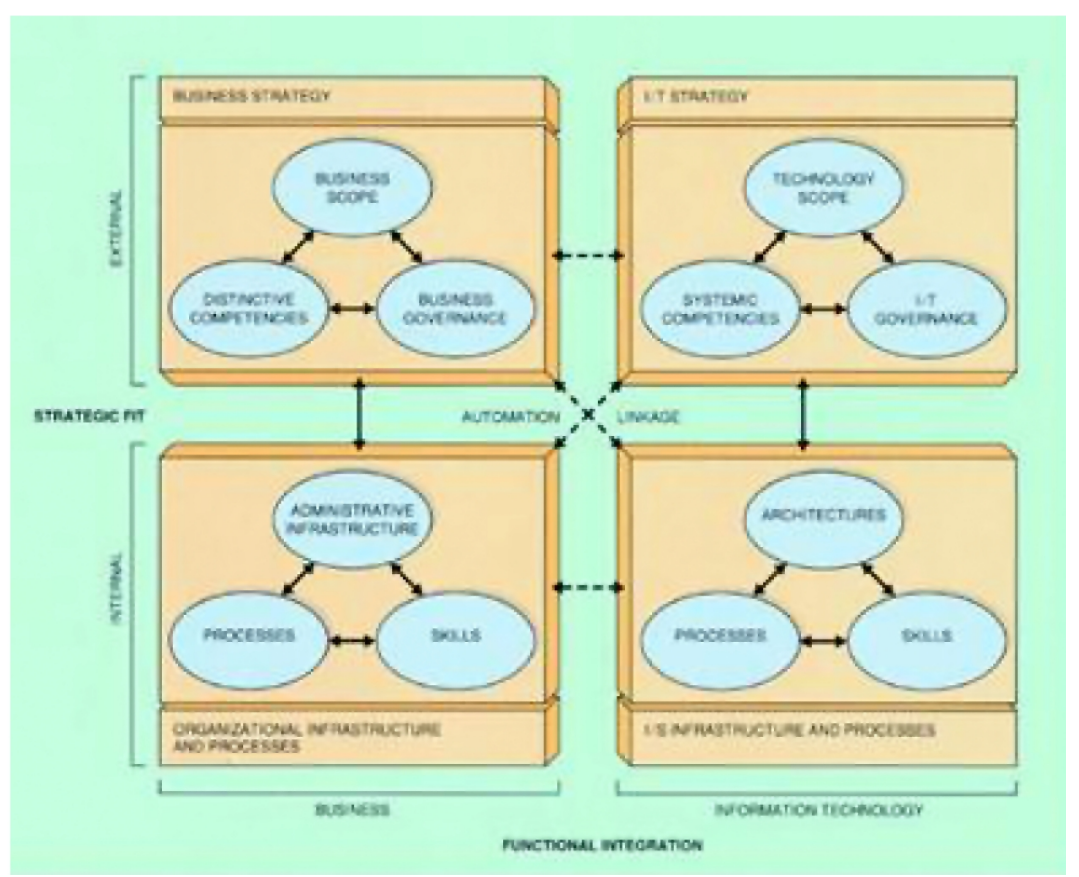

Figure 1. Strategic Alignment Model (Henderson \& Venkatraman, 1993)

Numerous literatures have agreed on the importance of IT-business strategic alignment in improving business performance (Chan \& Huff, 1993; Henderson \& Venkatraman, 1993; Kearns \& Lederer, 2000; Croteau \& Bergeron, 2001). Galliers and Newell (2003) argue that strategic alignment is the central principle of IS theories and practices. Though the importance of strategic alignment is well-understood, achieving and sustaining strategic alignment are still remaining two persistent issues. Previous studies shown that $72 \%$ of 594 IT executives consider IT-business strategic alignment as their main focus (Plowman, 1998) and it also has been top-ranked for the last ten years as important issue faced by executives (Henderson \& Venkatraman, 1993; Kempaiah, 2008). 
As aforementioned, the next important thing to focus on is how strategic alignment can be achieved and nurtured. Several strategic alignment frameworks have been proposed (Rockart \& Short, 1989; Hammer \& Champy, 1993) yet most of them were lack in providing a thorough roadmap to improve strategic alignment. An assessment framework also has been proposed by Reich and Benbasat (2000) yet it puts more focus on tactical level. Amongst strategic-level IT-business alignment frameworks (such as Segars, Grover \& Teng, 1998; Sabherwal \& Chan, 2001; Cragg, King \& Hussin, 2002; Kearns \& Lederer, 2003); Strategic Alignment Maturity Model (SAMM; Luftman, 2000) is considered as the most comprehensive one (Belfo \& Sousa, 2012). It has been validated to 25 Fortune 500 companies and used by 50 companies during its first year of publication (Luftman, 2000). In this approach, IT-business strategic alignment maturity is measured based on six criteria as listed in the following Table 1. SAMM consists of 39 items in total: 6 Communication-related items, 7 Value Measurement-related items, 7 Governance-related items, 6 Partnership-related items, 5 Scope and Architecture-related items, and 8 Skills-related items. Based on those six criteria, IT-business strategic alignment is classified into five maturity stages, that are: (1) Initial/Ad-hoc Process, (2) Committed Process, (3) Established Focus Process, (4) Improved/Managed Process, and (5) Optimized Process.

\begin{tabular}{|c|c|}
\hline SAMM's Criteria & Description \\
\hline $\begin{array}{l}\text { Communication } \\
\text { (COM) }\end{array}$ & $\begin{array}{l}\text { Effective exchange of ideas, information and knowledge between IT and business to ensure that } \\
\text { both parties have fully understood the strategy, priorities, processes and environmental } \\
\text { organizations required to obtain results desired. Six related attributes are: understanding of IT by } \\
\text { business and vice versa, inter/intra organizational learning, protocol rigidity, knowledge sharing, } \\
\text { and liaison effectiveness. }\end{array}$ \\
\hline $\begin{array}{l}\text { Value Measurement } \\
\text { (VAL) }\end{array}$ & $\begin{array}{l}\text { The use of measurements to illustrate IT contribution to the organization in terms that the business } \\
\text { understands. Seven related attributes are: IT and business metrics, balanced metrics, service level } \\
\text { agreements, benchmarking, formal assessments, and continuous improvement. }\end{array}$ \\
\hline Governance (GOV) & $\begin{array}{l}\text { The process of delegating IT decision making in management and the way business and IT } \\
\text { managers in prioritizing and allocating IT resources. Seven related attributes are: business and IT } \\
\text { strategic planning, organization structure, budgetary control, IT investment management, steering } \\
\text { committee, and prioritization process. }\end{array}$ \\
\hline Partnership (PRT) & $\begin{array}{l}\text { The relationship between IT and business including IT involvement in determining business } \\
\text { strategy, the degree of trust among them and how each values the contribution made by the other. } \\
\text { Six related attributes are: business perception of IT value, role of IT in strategic business planning, } \\
\text { shared goals, risk and rewards, IT program management, relationship style, and business sponsor. }\end{array}$ \\
\hline $\begin{array}{l}\text { Scope and } \\
\text { Architecture (ARC) }\end{array}$ & $\begin{array}{l}\text { IT ability in providing a flexible architecture, evaluating and implementing the technology, enabling } \\
\text { and controlling the business process, and providing solutions that can be customized to meet } \\
\text { internal needs and customer needs. Five related attributes are: the role of IT systems, IT standards } \\
\text { articulation, integration or IT architecture, architectural transparency and flexibility. }\end{array}$ \\
\hline Skills (SKI) & $\begin{array}{l}\text { All activities related to training, performance feedback, encouraging innovation and providing } \\
\text { employment opportunities. This criterion also includes IT's readiness for change and ability to } \\
\text { create new ideas. Related attributes are: innovation and entrepreneurship, locus of power, } \\
\text { management style, change readiness, career crossover, education and cross-training, and social } \\
\text { environment. }\end{array}$ \\
\hline
\end{tabular}

Table 1. IT-Business Strategic Alignment Maturity Model's Criteria (Luftman, 2000) 


\section{Hypotheses Development}

Prior research has highlighted the relationship between IT infrastructure flexibility and IT-business strategic alignment. IT infrastructure is considered to be flexible if it enables the creation of strategic innovation in business process (Duncan, 1995). Henderson and Venkatraman (1993) identify IT infrastructure flexibility as mechanism needed to achieve strategic alignment. Both IT infrastructure flexibility and strategic alignment are necessary to predict the future business value (Tallon \& Kraemer, 2003). Furthermore, a positive relationship between IT infrastructure flexibility and IT-business strategic alignment also has been identified (Tallon \& Kraemer, 2003; Ness, 2005). Specifically, Chung et al. (2003) pinpoint a positive and significant impact from connectivity, compatibility, modularity and IT personnel flexibility to IT-business strategic alignment. Therefore, we propose the following hypotheses:

\section{H1: IT infrastructure connectivity has a positive impact on IT-business strategic alignment}

\section{H2: IT infrastructure modularity has a positive impact on IT-business strategic alignment}

\section{H3: IT infrastructure compatibility has a positive impact on IT-business strategic alignment}

\section{H4: IT personnel flexibility has a positive impact on IT-business strategic alignment}

This study aimed to explore the impacts of IT infrastructure flexibility on IT-business strategic alignment. Four previously discussed components of IT infrastructure flexibility (connectivity, modularity, compatibility, and IT personnel flexibility) are applied as exogenous (independent) latent variables. ITbusiness strategic alignment is modeled as a second-order endogenous latent variable, composed of six Luftman's strategic alignment maturity criteria as its first-order variables. Reflective approach is used in modeling the relationships between variables and their indicators as the indicators used are the manifestation of their variables, rather than defining them (Jarvis, Mackenzie \& Podsakoff, 2003). The conceptual model of this study is presented in Figure 2.

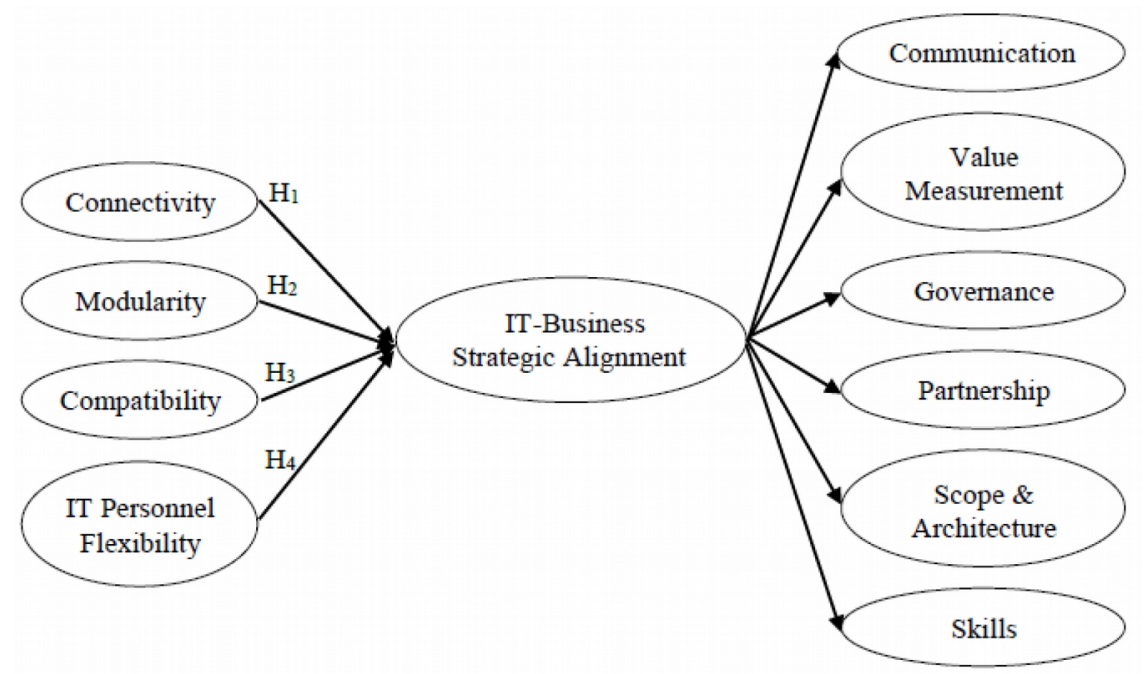

Figure 2. Conceptual Model 


\section{Methodology}

\subsection{Research Stages}

As seen in Figure 3, this research generally consists of five stages. The first stage is the preparation, which at this stage we formulate the research problems and the scope to be studied, review the literature to explore concepts related to our research, and formulate the hypotheses. The second stage is the research design, which at this stage we determine population and sample, develop research models, prepare research instruments, and conduct a pilot study. The third stage is the data collection, which includes the distribution of questionnaires to a sample as well as verification of collected data. Stage four is the data analysis stage, which at this stage we test the reliability and validity of the measurement models and structural models. The fifth stage, we draw conclusions based on analyses that have been done as well as formulate recommendations for future research.

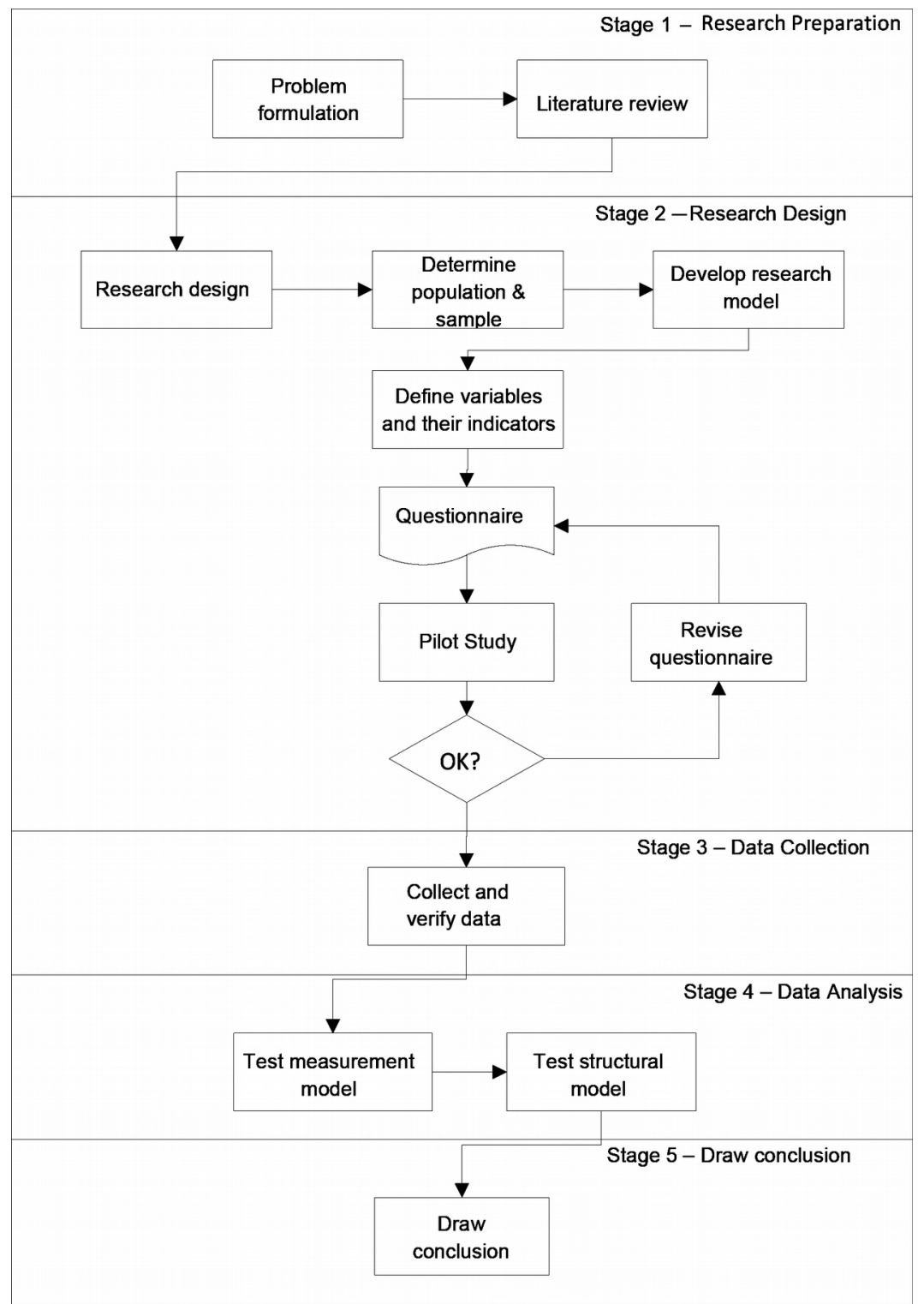

Figure 3. Research stages 


\subsection{Instrument Development}

In general, the instrument of this research consists of two main parts: questions related to IT infrastructure flexibility and questions related to IT-business strategic alignment. Items related to IT infrastructure flexibility were derived from several previous literatures (Nelson, 1991; Duncan, 1995; Byrd \& Turner, 2000; Chung et al., 2003; Tallon \& Kraemer 2003; Ness, 2005; Paschke, Molla \& Matin, 2008; Fink \& Neumann, 2009; Masrek \& Jusoff, 2009; Tallon \& Pinsonneault, 2011). It consists of: 5 connectivity-related items, 6 modularity-related items, 4 compatibility-related items, and 7-IT personnel flexibility-related items. Meanwhile, IT-business strategic alignment was measured by adopting 39 Luftman's items, consists of: 6 communication-related items, 7 value measurement-related items, 7 governance-related items, 6 partnership-related items, 6 scope and architecture-related items and 8 skillsrelated items. For each items, respondents were asked to choose one out of five-point Likert scale. In IT infrastructure flexibility instruments, the scales are ranging from "completely disagree" (1) to "completely agree" (5). On the other hand, for the instruments of IT-business strategic alignment, each scale specifies particular condition needed to be fulfilled on associated maturity level. The complete questionnaire can be found in the Annex A.

\subsection{Data Collection}

This research was conducted using questionnaire distributed either through online media or direct meet up with the respondents. Population of this research covers all companies located in Indonesia that have more than 500 employees, both private companies, state-owned enterprises and government institutions. Questionnaire was distributed to IT managers/staffs who have worked on associated company for at least 2 years. 48 samples were collected using convenience sampling due to the very large population size with each sample represents one company. All responses were usable based on the outlier test conducted with WarpPLS. As for the minimum sample size to be analyzed using PLS, the minimum sample size for reflective model should be equal to or more than ten times the number of directed paths in structural (inner) model (Barclay, Higgins \& Thompson, 1995). In this research model, there are four directed paths on the structural model (connectivity-strategic alignment, modularitystrategic alignment, compatibility-strategic alignment, and IT personnel flexibility-strategic alignment), so based on Barclay's theory, the minimum sample size for this research model should be equal to or more than forty. Thus, the sample size of 48 surpasses this requirement and is considered to be adequate to be processed further. The demographic characteristics from the collected samples are provided on Table 2 below. 


\begin{tabular}{|c|c|c|c|c|c|c|c|c|c|c|c|}
\hline \multicolumn{2}{|c|}{ Company Type } & \multicolumn{2}{|c|}{ Industry Sector } & \multicolumn{2}{|c|}{$\begin{array}{l}\text { No. of } \\
\text { Employees } \\
\text { (thousand) }\end{array}$} & \multicolumn{2}{|c|}{$\begin{array}{l}\text { Annual IT } \\
\text { Budgets (billion) }\end{array}$} & \multicolumn{2}{|c|}{ Title } & \multicolumn{2}{|c|}{$\begin{array}{l}\text { Tenure } \\
\text { (year) }\end{array}$} \\
\hline Private & $67 \%$ & Automotive & $11 \%$ & $\leq 1$ & $40 \%$ & $\leq 1$ & $27 \%$ & IT staff & $46 \%$ & 2 to 5 & $52 \%$ \\
\hline State-owned & $25 \%$ & Construction & $6 \%$ & $>1$ to 5 & $29 \%$ & $>1$ to 50 & $56 \%$ & $\begin{array}{l}\text { IT senior } \\
\text { officer }\end{array}$ & $23 \%$ & $>5$ to 10 & $33 \%$ \\
\hline \multirow[t]{9}{*}{$\begin{array}{l}\text { Gov. } \\
\text { institution }\end{array}$} & $8 \%$ & Financial services & $19 \%$ & $>5$ to 10 & $6 \%$ & $>50$ to 100 & $6 \%$ & $\begin{array}{c}\text { IT } \\
\text { manager }\end{array}$ & $27 \%$ & $>10$ & $15 \%$ \\
\hline & & FMCG & $2 \%$ & $>10$ & $25 \%$ & $>100$ & $11 \%$ & VP of IT & $4 \%$ & & \\
\hline & & Forestry & $2 \%$ & & & & & & & & \\
\hline & & IT & $31 \%$ & & & & & & & & \\
\hline & & Manufacture & $8 \%$ & & & & & & & & \\
\hline & & Mining & $6 \%$ & & & & & & & & \\
\hline & & Property & $2 \%$ & & & & & & & & \\
\hline & & Public service & $11 \%$ & & & & & & & & \\
\hline & & Transportation & $2 \%$ & & & & & & & & \\
\hline
\end{tabular}

Table 2. Demographic characteristics of respondents

\section{Results}

A partial least squares (PLS) approach was used to analyze the data and test the hypothesis. Unlike covariance-based Structural Equation Modeling (CBSEM), PLS attempts to minimize the variance of all endogenous variables and more suitable for examing predictive relationships with sample size between 30-100 (Wold, 1985; Chin \& Newsted, 1999; Henseler, Ringle \& Sinkovics, 2009). Considering that we only have a small number of respondents $(n=48)$, PLS is the most appropriate approach as it works well in small sample size (Fornell \& Bookstein, 1982), although it also has higher risk of overlooking real correlation and sensitivity to the relative scaling of the descriptor variables (Cramer III, 1993). PLS is also suitable for examining the predictive relationship, particularly when developing model with little rigorous theory grounding (Fornell \& Bookstein, 1982). Thus, we applied PLS approach in this research by using WarpPLS version 3.0. 


\subsection{Measurement Model Evaluation}

\subsubsection{Evaluation of First-Order Latent Variables}

To evaluate the measurement model, we assessed the indicator reliability, internal consistency reliability, convergent validity, and discriminant validity. As recommended by Wetzels, OdekerkenSchröder and van Oppen (2009), to analyze a model with second-order variable, we firstly have to construct the null model - a model that only contains first-order latent variables with no structural relationship among variables. Null model is needed to assess the psychometric properties of the measures such as indicator loadings, Cronbach's Alpha (CA), composite reliability (CR), and average variance extracted (AVE), for the first-order latent variable. Indicator reliability was assessed using indicator loadings, based on the premise that an indicator is considered to be reliable if its loading $\geq$ 0.707 (Carmines \& Zeller 1978; Chin, 1998). From Table 3, it can be seen that nine indicator loadings are lower than the threshold, that are: CNC3 (0.634), CNC4 (0.679), MOD5 (0.636), MOD6 (0.628), ITP2 (0.706), GOV3 (0.600), GOV4 (0.648), SKI2 (0.664) and SKI3 (0.598). According to Urbach and Ahlemann (2010), indicators that do not satisfy indicator reliability could be removed from the model. However, indicator with loading between 0.4-0.7 are allowed to be retained in the model as long as the model satisfies the validity test (Hair, Ringle \& Sarstedt, 2011). Thus, these nine indicators are temporarily retained - if they do not satisfy the next validity test, they have to be removed from the model.

To demonstrate internal consistency reliability, latent variables should have CA and CR more than 0.700 (Werts, Linn \& Jöreskog, 1974; Cronbach, 1951; Nunally \& Bernstein, 1994). According to the result, the CA and CR for all first-order latent variables are above 0.700 , and hence, exhibit internal consistency reliability. In addition, to test the convergent validity, AVE for each latent variable should equal or more than 0.500 (Fornell \& Larcker, 1981). The AVE for all first-order latent variables are ranging from $0.516-0.774$ (see Table 3), thus satisfy convergent validity. Finally, to achieve discriminant validity, square-rooted AVE should be larger than the shared variance (correlation) among latent variables (Fornell \& Larcker, 1981). Table 4 shows that only modularity, compatibility and IT personnel flexibility that have fulfilled this criterion. To handle insufficiency of discriminant validity, Farrell (2010) recommends to remove indicators that cross-load on more than one latent variable. By the same token, Chin (1998) specifies that to satisfy discriminant validity, (1) each indicator should have its highest loading on its associated latent variable rather than on other latent variables, and (2) each latent variable should load highest with its own indicators. According to that, 15 indicators were removed from the model, that are: CNC3, COM1, COM2, COM6, VAL5, VAL7, GOV3, GOV4, GOV5, GOV7, PRT3, PRT6, SKI2, SKI3, and SKI5. After removing those 15 indicators, discriminant validity was met. 


\begin{tabular}{|c|c|c|c|c|c|c|c|c|c|}
\hline Code & Loadings & CA & CR & AVE & Code & Loadings & CA & CR & AVE \\
\hline \multicolumn{2}{|c|}{ Connectivity } & 0.762 & 0.841 & 0.516 & \multicolumn{2}{|c|}{ Value Measurement } & 0.951 & 0.96 & 0.774 \\
\hline $\mathrm{CNC1}$ & 0.827 & & & & VAL1 & 0.853 & & & \\
\hline $\mathrm{CNC} 2$ & 0.718 & & & & VAL2 & 0.896 & & & \\
\hline CNC3 & 0.634 & & & & VAL3 & 0.95 & & & \\
\hline $\mathrm{CNC4}$ & 0.679 & & & & VAL4 & 0.864 & & & \\
\hline CNC5 & 0.72 & & & & VAL5 & 0.828 & & & \\
\hline \multicolumn{2}{|c|}{ Modularity } & 0.861 & 0.897 & 0.597 & VAL6 & 0.913 & & & \\
\hline MOD1 & 0.803 & & & & VAL7 & 0.846 & & & \\
\hline MOD2 & 0.882 & & & & \multicolumn{2}{|c|}{ Governance } & 0.893 & 0.918 & 0.620 \\
\hline MOD3 & 0.814 & & & & GOV1 & 0.897 & & & \\
\hline MOD4 & 0.834 & & & & GOV2 & 0.888 & & & \\
\hline MOD5 & 0.636 & & & & GOV3 & 0.6 & & & \\
\hline MOD6 & 0.628 & & & & GOV4 & 0.648 & & & \\
\hline \multicolumn{2}{|c|}{ Compatibility } & 0.848 & 0.898 & 0.690 & GOV5 & 0.779 & & & \\
\hline CMP1 & 0.756 & & & & GOV6 & 0.885 & & & \\
\hline CMP2 & 0.9 & & & & GOV7 & 0.758 & & & \\
\hline CMP3 & 0.871 & & & & \multicolumn{2}{|c|}{ Partnership } & 0.938 & 0.952 & 0.767 \\
\hline CMP4 & 0.787 & & & & PRT1 & 0.868 & & & \\
\hline \multicolumn{2}{|c|}{ IT Personnel Flexibility } & 0.903 & 0.923 & 0.634 & PRT2 & 0.899 & & & \\
\hline ITP1 & 0.835 & & & & PRT3 & 0.842 & & & \\
\hline ITP2 & 0.706 & & & & PRT4 & 0.902 & & & \\
\hline ITP3 & 0.861 & & & & PRT5 & 0.943 & & & \\
\hline ITP4 & 0.766 & & & & PRT6 & 0.793 & & & \\
\hline ITP5 & 0.864 & & & & \multicolumn{2}{|c|}{ Scope and Architecture } & 0.925 & 0.944 & 0.771 \\
\hline ITP6 & 0.739 & & & & ARC1 & 0.864 & & & \\
\hline ITP7 & 0.789 & & & & ARC2 & 0.916 & & & \\
\hline \multicolumn{2}{|c|}{ Communication } & 0.906 & 0.928 & 0.682 & ARC3 & 0.845 & & & \\
\hline COM1 & 0.809 & & & & ARC4 & 0.898 & & & \\
\hline COM2 & 0.818 & & & & ARC5 & 0.865 & & & \\
\hline COM3 & 0.859 & & & & \multicolumn{2}{|c|}{ Skills } & 0.929 & 0.943 & 0.678 \\
\hline COM4 & 0.859 & & & & SKI1 & 0.828 & & & \\
\hline COM5 & 0.86 & & & & $\mathrm{SKI} 2$ & 0.664 & & & \\
\hline \multirow[t]{6}{*}{ COM6 } & 0.743 & & & & $\mathrm{SKI} 3$ & 0.598 & & & \\
\hline & & & & & $\mathrm{SKI} 4$ & 0.899 & & & \\
\hline & & & & & SKI5 & 0.827 & & & \\
\hline & & & & & SKI6 & 0.917 & & & \\
\hline & & & & & SKI7 & 0.879 & & & \\
\hline & & & & & SKI8 & 0.915 & & & \\
\hline
\end{tabular}

Table 3. Psychometric properties of measurement model (null model) 


\begin{tabular}{|c|r|r|r|r|r|r|r|r|r|r|}
\hline & \multicolumn{1}{|c|}{ CNC } & \multicolumn{1}{c|}{ MOD } & \multicolumn{1}{c|}{ CMP } & \multicolumn{1}{c|}{ ITP } & COM & VAL & GOV & PRT & ARC & SKI \\
\hline CNC & 0.718 & & & & & & & & & \\
\hline MOD & 0.679 & 0.772 & & & & & & & & \\
\hline CMP & 0.733 & 0.731 & 0.831 & & & & & & & \\
\hline ITP & 0.673 & 0.482 & 0.694 & 0.796 & & & & & & \\
\hline COM & 0.597 & 0.533 & 0.695 & 0.609 & 0.826 & & & & & \\
\hline VAL & 0.515 & 0.480 & 0.658 & 0.530 & 0.843 & 0.880 & & & & \\
\hline GOV & 0.522 & 0.490 & 0.644 & 0.563 & 0.854 & 0.898 & 0.787 & & & \\
\hline PRT & 0.532 & 0.608 & 0.711 & 0.475 & 0.861 & 0.846 & 0.877 & 0.876 & & \\
\hline ARC & 0.598 & 0.556 & 0.685 & 0.543 & 0.783 & 0.867 & 0.891 & 0.883 & 0.878 & \\
\hline SKI & 0.518 & 0.50 & 0.648 & 0.550 & 0.885 & 0.860 & 0.869 & 0.916 & 0.868 & 0.824 \\
\hline
\end{tabular}

Note: square roots of average variances extracted (AVE's) shown on diagonal. $*_{\mathrm{p}}<0.001$

Table 4. Square-rooted AVE and latent variable correlations (before indicators removal)

\subsubsection{Evaluation of Second-Order Latent Variables}

Second-order variable is modeled through repeated indicators/hierarchical component model approach (Wold, 1985). By applying this approach, the factor values of COM, VAL, GOV, PRT, ARC, and SKI (obtained from the null model) are used to determine the value of IT-business strategic alignment (LSA). As recommended by Wetzels et al. (2009), reflective second-order latent variable is evaluated based on the value of CA, CR, and AVE. With indicator loadings for its six variables ranging from 0.923-0.954 $(\mathrm{p}<0.001), \mathrm{CA}=0.975, \mathrm{CR}=0.980$, and AVE $=0.889, \mathrm{LSA}$ satisfy the reliability and validity tests. Therefore, the overall measurement model has been successfully validated.

\subsection{Structural Model Evaluation}

As suggested by Urbach and Ahlemann (2010), the structural model was evaluated based on coefficient of determination (R2), path coefficient ( $\beta$ ), Cohen's effect size (f2), and predictive relevance (Q2). The R2 for all latent variables is ranging from $0.446-0.914$ and considered to be substantial and has explanatory power as it is higher than 0.333 (Chin, 1998). According to Huber, Herrmann, Meyer, Vogel and Wollhardt (2007), a path coefficient should exceed 0.100 to account for certain impact on the model. This path also has to be significant at least on $\alpha=0.05$ that can be tested through resampling method, i.e jackniffing. As seen in Figure 4, path coefficient is found to be significant only between CMP-LSA with path coefficient 0.5 . The path coefficient between CNC-LSA is not significant on $\alpha=0.05$ though it exceeds the threshold of 0.100. In addition, an effect size is considered to be low if it is between 0.02 and 0.150, medium if f2 between 0.150-0.350, and high if f $2>0.350$. (Cohen, 1988; Chin, 1998). Based on 
this rule of thumb, only compatibility that is found to be highly significant with effect size 0.362 (see Table 5). Meanwhile, as stated by Stone (1974) and Geisser (1975), the positive Q2 indicates that the prediction made by the model is considered to be relevant.

According to this result, the third hypothesis was supported as there is a positive and significant impact between compatibility and IT-business strategic alignment. On the other hand, the impacts given by connectivity, modularity and IT personnel flexibility to IT-business strategic alignment are not quite significant, and hence the other hypotheses (H1, H2, and H4) were not supported.

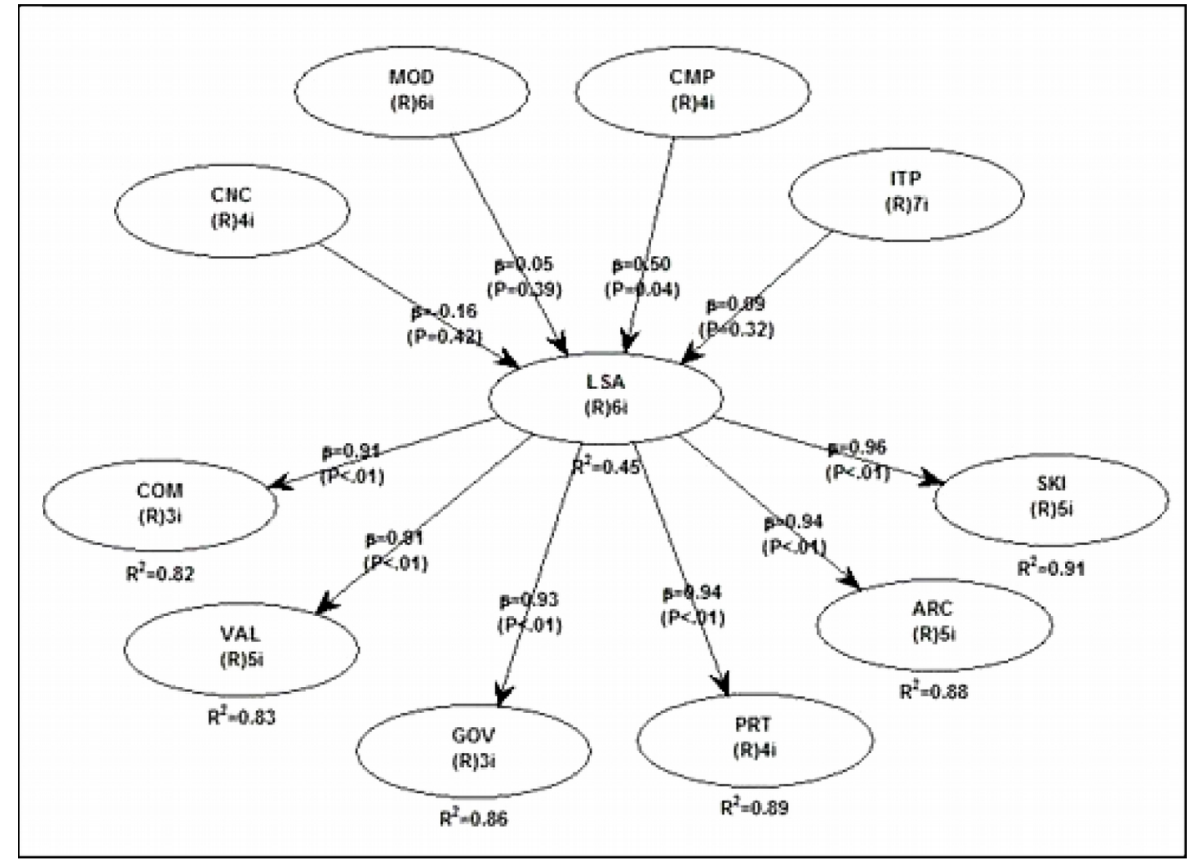

Figure 4. Path coefficient

\begin{tabular}{|c|c|c|c|c|c|c|c|c|c|c|c|c|}
\hline \multicolumn{2}{|c|}{ COM } & VAL & GOV & PRT & ARC & SKI & LSA & CNC & MOD & CMP & ITP \\
\hline COM & & & & & & & 0.820 & & & & \\
\hline VAL & & & & & & & 0.834 & & & & \\
\hline GOV & & & & & & & 0.859 & & & & \\
\hline PRT & & & & & & & 0.886 & & & & \\
\hline ARC & & & & & & 0.876 & & & & \\
\hline SKI & & & & & & & 0.914 & & & & \\
\hline LSA & & & & & & & & 0.102 & 0.030 & 0.362 & 0.054 \\
\hline CNC & & & & & & & & & & & \\
\hline MOD & & & & & & & & & & & \\
\hline CMP & & & & & & & & & & & \\
\hline ITP & & & & & & & & & & & \\
\hline $\boldsymbol{R}^{2}$ & 0.820 & 0.834 & 0.859 & 0.886 & 0.876 & 0.914 & 0.446 & & & & \\
\hline $\boldsymbol{Q}^{2}$ & 0.819 & 0.836 & 0.858 & 0.888 & 0.879 & 0.915 & 0.444 & & & & \\
\hline
\end{tabular}

Table 5. Psychometric properties of structural model 


\section{Discussion and Implications}

\subsection{Discussion}

Based on the analysis performed, only compatibility has positive and significant impact on strategic alignment. In the Luftman strategic alignment model, strategic alignment is measured in detail by paying attention to the technical aspects (scope and architecture for example) as well as humanist (expertise) aspect, both in business and IT. As a humanist component of the IT infrastructure flexibility, this study found that the adaptability of IT personnel only shows a strong positive influence on the governance and expertise aspects. This is not surprising given that these aspects are focused on competence and participation of IT and business personnel.

This study shows that only compatibility a positive influence on strategic alignment. This indicates that the ability of the organization to be able to distribute the appropriate information to the organization's internal and external parties is a determinant of achieving strategic alignment. The availability of such information allows the business can take many important decisions, to achieve the desired performance by business.

In addition, compatibility also enables IT personnel become powerful, allowing IT capability in the organization to be improved. Improved IT capability certainly had an impact on business, as more and more business activities that can be supported by IT. This led to a business view that IT has given value to the business that led to their good relationship between business and IT.

Here elaborated further on the influence exerted on each component of the IT infrastructure flexibility.

\subsubsection{Connectivity - Strategic Alignment}

Connectivity represents the extent to which the IT infrastructure components are connected to each other both in the internal and external companies (Duncan, 1995). This component also represents a degree of coverage area that can be reached by a technology platform (Keen, 1991). In general, the study found that connectivity does not have a significant positive effect on the strategic alignment. This is in contrast with the findings of Chung et al. (2003) which states that connectivity provides significant positive influence on the strategic alignment. Connectivity allows a faster response to changes in business strategy. A high level of connectivity facilitates the exchange of ideas and information in a more easily so that it is expected to increase the maturity of communication in the organization. In addition, the higher level of connectivity indicates better IT capabilities and an integrated system that positively affects the scope and architecture maturity. However, this study showed that connectivity has a significant negative relationship to the strategic alignment. 


\subsubsection{Modularity - Strategic Alignment}

Modularity represents the ability to reconfigure the software, hardware and data with ease and without cause fatal damage to meet business needs (Duncan, 1995). Similar to connectivity, modularity also found not to give a significant positive effect on the strategic alignment. It is also contrary to the findings of Chung et al. (2003) that show modularity has a significant positive influence on strategic alignment because it allows a faster response to changes in business strategy. In this study, modularity actually has a positive influence on strategic alignment, but the effect is not significant. Although modularity is found not to give significant influence, higher IT systems modularity are expected to be better enabling IT personnel to more easily develop technical solutions according to business unit requests. It can stimulate understanding and a better appreciation of the contribution made by both sides so that the maturity of the partnership of business and IT is expected to increase.

\subsubsection{Compatibility - Strategic Alignment}

Compatibility represents the ability to distribute any information either internally or externally (Duncan, 1995). Unlike the two previous components, compatibility shows a significant positive influence on strategic alignment. Interestingly, these findings again in contrast to the results of Chung et al. (2003) which states that of the four components of the IT infrastructure flexibility, compatibility not only has a significant positive effect on the strategic alignment. In his research, Chung et al. (2003) measured strategic alignment by the degree of business-IT alignment strategy, user participation in IT planning, the degree of alignment of IT investments and spending towards business objectives and priorities, as well as the degree of integration of the IT Division to the overall structure of the organizational structure. Chung et al. (2003) argued that the indicators used to measure the compatibility of the research are of a technical nature while the strategic alignment indicator is otherwise so that the respondent may argue that this is too technical aspect and has nothing to do with the business (strategic alignment). This is different from this study where strategic alignment is measured by considering the technical aspects as well as business aspects so that the influence of compatibility can be detected. 


\subsubsection{The Adaptability of IT Personnel - Strategic Alignment}

Adaptability of IT personnel represents the ability of IT personnel to adapt to changes in business strategy and work cooperatively across functional units (Masrek \& Jusoff, 2009). The analysis result showed that the adaptability of IT personnel does not show a significant positive effect on the strategic alignment. In Chung et al. (2003) findings, this component has positive influence on strategic alignment as it is considered to facilitate connectivity and modularity so that the company can respond to changes quickly. Adaptability of IT personnel actually had a positive influence nearly as significant (path coefficient $=0.09)$, however the coefficient is a little below the threshold $(0.100)$ so that the effect is considered not significant.

\subsection{Implications}

As one of the efforts to achieve strategic alignment, building a flexible IT infrastructure requires significant investment. The findings of this study can be input to get around the lack of investment by first focusing on the development of IT infrastructure components which are considered having the most significant influence on strategic alignment. Among the four components of the IT infrastructure flexibility, only compatibility is proven to have a significant positive effect on strategic alignment so that the compatibility component should receive more attention in order to achieve strategic alignment. From theoretical aspect, the results of this study confirm earlier findings that IT flexibility is one of the key factors to achieve business-IT strategic alignment.

\section{Conclusion}

The main objective of this research was to explore the impacts of IT infrastructure flexibility components on IT-business strategic alignment. This study found that amongst four components of IT infrastructure flexibility, only compatibility that has a positive and significant impact on IT-business strategic alignment. The other three components actually demonstrated a positive impact on IT-business strategic alignment, yet the impacts given are insignificant. However, we suggest that a flexible IT infrastructure is still important in fostering alignment between IT and business strategy.

This study is limited to two remarkable points. First, though the samples used in this study has satisfied the minimum requirement, the sample size, however, is quite small. Using a larger sample size and a better sampling technique could improve the reliability of the findings. Second, the research used single- 
source data in which each respondent represents different company. A multi-source data would be preferred to provide a more dependable result.

This study uses the Luftman strategic alignment model which assessing the strategic alignment based on the level of maturity of the components of strategic alignment. There are other models of strategic alignment as proposed by Tallon-Kraemer which looking at the strategic alignment as the interaction between business and IT on six key areas of the value chain. For further research, we can compare the results obtained from both models, so that the effect of IT infrastructure flexibility to strategic alignment can be seen with more detail.

\section{Acknowledgment}

This research was supported by Multi-discipline Research Grant Universitas Indonesia, No. 1606/UN2.R12/HKP.05.00/2015. The authors would like to gratefully acknowledge the insightful reviews and suggestions from the reviewers on the earlier version of this paper. Their comments have substantially helped to the paper improvement. We would also like to thank our faculty and our university for their continuous support to enhance the quality of our research.

\section{References}

Akhtar, M., \& Mittal, R.K. (2014). Strategic Flexibility, Information System Flexibility and Enterprise Performance Management. In Organisational Flexibility and Competitiveness (pp. 41-51). Springer India. http://dx.doi.org/10.1007/978-81-322-1668-1_4

Alaeddini, M., \& Salekfard, S. (2013). Investigating the role of an enterprise architecture project in the business-IT alignment in Iran. Information Systems Frontiers, 15(1), 67-88. http://dx.doi.org/10.1007/s10796$011-9332-y$

Allen, B.R., \& Boynton, A.C. (1991). Information architecture: in search of efficient flexibility. MIS Quarterly, 15(4), 435-445. http://dx.doi.org/10.2307/249447

Avison, D., Jones, J., Powell, P., \& Wilson, D. (2004). Using and validating the strategic alignment model. Journal of Strategic Information Systems, 13(3), 223-246. http://dx.doi.org/10.1016/j.jsis.2004.08.002

Barclay, D., Higgins, C., \& Thompson, R. (1995). The partial least squares (PLS) approach to causal modeling: Personal computer adoption and use as an illustration. Technology Studies, 2, 285-309. 
Belfo, F.P., \& Sousa, R.D. (2012). A critical review of Luftman's instrument for business-IT alignment. In MCIS 2012 Proceedings, 6. Guimaraes, Portugal.

Brancheau, J.C., Janz, B.D., \& Wetherbe, J.C. (1996). Key issues in information systems management: 1994-95 SIM Delphi results. MIS Quarterly, 10(2), 225-242. http://dx.doi.org/10.2307/249479

Broadbent, M., Weill, P., \& Neo, B.S. (1999). Strategic Context and Patterns of IT Infrastructure Capability. Journal of Strategic Information Systems, 8(2), 157-187. http://dx.doi.org/10.1016/S0963-8687(99)000220

Broadbent, M., Weill, P., O'Brien, T., \& Neo, B.S. (1996). Firm context and patterns of IT infrastructure capability. In Proceedings of the Seventeenth International Conference on Information Systems, 174-194.

Byrd, T.A. \& Turner, D.E. (2000). Measuring the flexibility of information technology infrastructure: exploratory analysis of a construct. Journal of Management Information Systems, 17 (1), 167-208.

Carmines, E.G., \& Zeller, R.A. (1979). Reliability and Validity Assessment. Sage University Paper Series on Quantitative Applications in the Social Sciences. Sage, Beverly Hills, CA. http://dx.doi.org/10.4135/9781412985642

Chan, Y., \& Huff, S. (1993). Strategic information systems alignment. Business Quarterly, 58 (1), 51-56.

Chan, Y.E., Huff, S.L., Barclay, D.W., \& Copeland, D.G. (1997). Business strategic orientation, information systems strategic orientation, and strategic alignment. Information systems research, 8(2), 125-150. http://dx.doi.org/10.1287/isre.8.2.125

Charoensuk, S., Wongsurawat, W., \& Khang, D.B. (2014). Business-IT Alignment: A practical research approach. The Journal of High Technology Management Research, 25(2), 132-147. http://dx.doi.org/10.1016/j.hitech.2014.07.002

Chiang, I.R., \& Nunez, M.A. (2013). Strategic alignment and value maximization for IT project portfolios. Information Technology and Management, 14(2), 143-157. http://dx.doi.org/10.1007/s10799-012-0126-9

Chin, W.W. (1998). The Partial Least Squares Approach to Structural Equation Modeling. Modern Methods for Business Research. G.A. Marcoulides (Eds.) (pp. 1295-1336). NJ: Lawrence Erlbaum Associates.

Chin, W.W., \& Newsted, P.R. (1999). Structural equation modeling analysis with small samples using partial least squares. In Hoyle, R. (Ed.). Statistical Strategies for Small Sample Research. Sage Publications, CA. $1307-1341$. 
Chung, S.H., Rainer Jr., R.K., \& Lewis, B.R. (2003). The impact of information technology infrastructure flexibility on strategic alignment and application implementations. Communications of the Association for Information Systems, 11 (11).

Cohen, J. (1988). Statistical Power Analysis for the Behavioral Sciences. Hillsdale, NJ: Lawrence Erlbaum.

Cragg, P., King, M., \& Hussin, H. (2002). IT alignment and firm performance in small manufacturing firms. The Journal of Strategic Information Systems, 11 (2), 109-132. http://dx.doi.org/10.1016/S09638687(02)00007-0

Cramer III, R.D. (1993). Partial least squares (PLS): its strengths and limitations. Perspectives in Drug Discovery and Design, 1(2), 269-278. http://dx.doi.org/10.1007/BF02174528

Cronbach, L.J. (1951). Coefficient alpha and the internal structure of tests. Psychometrika, 16 (3), 297-334. http://dx.doi.org/10.1007/BF02310555

Croteau, A.M., \& Bergeron, F. (2001). An information technology trilogy: Business strategy, technology deployment and organisational performance. Strategic Information Systems, 10, 77-99. http://dx.doi.org/10.1016/S0963-8687(01)00044-0

Davenport, T.H., \& Linder, J. (1994). Information management infrastructure: The new competitive weapon. In Proceedings of the 27th Annual Hawaii International Conference on Systems Sciences. Hawaii, 885-899. http://dx.doi.org/10.1109/hicss.1994.323420

De Leeuw, A.C. J., \& Volberda, H.W. (1996). On the concept of flexibility: A dual control perspective. Omega, 24 (2), 121-139. http://dx.doi.org/10.1016/0305-0483(95)00054-2

Duncan, N.B. (1995). Capturing flexibility of information technology infrastructure: A study of resource characteristics and their measure. Journal of Management Information Systems, 12 (2), 37-57. http://dx.doi.org/10.1080/07421222.1995.11518080

Earl, M.J. (1989). Management Strategies for Information Technology. Prentice-Hall, London.

Farrell, A.M. (2010). Insufficient discriminant validity: A comment on Bove, Pervan, Beatty, and Shiu (2009). Journal of Business Research, 63, 324-327. http://dx.doi.org/10.1016/j.jbusres.2009.05.003

Feidler, K.D., Gorver, V., \& Teng, J.T.C. (1995). An Empirical Study of Information Technology Enabled Business Process Redesign and Corporate Competitive Strategy. European Journal of Information Systems, 4(1), 17-30. http://dx.doi.org/10.1057/ejis.1995.3 
Fink, L. \& Neumann, S. (2009). Exploring the perceived business value of the flexibility enabled by information technology infrastructure. Information \& Management, 46, 90-99. http://dx.doi.org/10.1016/j.im.2008.11.007

Fornell, C., \& Bookstein, F. (1982). Two structural equation models: LISREL and PLS applied to consumer exit-voice theory. Journal of Marketing Research, 19, 440-452. http://dx.doi.org/10.2307/3151718

Fornell, C., \& Larcker, D.F. (1981). Evaluating structural equation models with unobservable variables and measurement error. Journal of Marketing Research, 18, 39-50. http://dx.doi.org/10.2307/3151312

Galliers, R., \& Newell, S. (2003). Strategy as Data + Sense Making. Oxford.

Geisser, S. (1975). The redictive sample reuse method with applications. Journal of the American Statistical Association, 70, 320-328. http://dx.doi.org/10.1080/01621459.1975.10479865

Gerow, J.E., Grover, V., Thatcher, J.B., \& Roth, P.L. (2014). Looking Toward the Future of IT-Business Strategic Alignment through the Past: A Meta-Analysis. Mis Quarterly, 38(4), 1059-1085.

Gross, J.R., \& Raymond, B. (1993). Total flexibility management: A managerial approach for developing flexible resources. Industrial Management, 35, 21.

Hair, J.F., Ringle, C.M., \& Sarstedt, M. (2011). PLS-SEM: Indeed a silver bullet. Journal of Marketing Theory and Practice, 19 (2), 139-151. http://dx.doi.org/10.2753/MTP1069-6679190202

Hammer, M., \& Champy, J. (1993). Reengineering the corporation: A manifesto for business revolution. Harper Business. http://dx.doi.org/10.1016/s0007-6813(05)80064-3

Henderson, J.C., \& Venkatraman, N. (1993). Strategic alignment: Leveraging information technology for transforming organizations. IBM Systems Journal, 32 (1), 4-16. http://dx.doi.org/10.1147/sj.382.0472

Henseler, J., Ringle, C.M., \& Sinkovics, R.R. (2009). The use of partial least squares path modeling in international marketing. Advances in International Marketing, 20, 277-320. http://dx.doi.org/10.1108/S14747979(2009)0000020014

Huber, F., Herrmann, A., Meyer, F., Vogel, J., \& Wollhardt, K. (2007). Kausalmodellierung mit Partial Least Squares-Eine anwendungsorientierte Einfübrung. Gabler, Wiesbaden.

Jarvis, C.B., Mackenzie, S.B., \& Podsakoff, P.M. (2003). A critical review of construct indicators and measurement model misspecification in marketing and consumer research. Journal of Consumer Research, 30 (2), 199-218. http://dx.doi.org/10.1086/376806 
Jorfi, S., Nor, K.M., Najjar, L., \& Jorfi, H. (2011). The impact of IT flexibility on strategic alignment (with focus on export). International Journal of Business and Management, 6(8), 264. http://dx.doi.org/10.5539/ijbm.v6n8p264

Kearns, G.S., \& Lederer, A.L. (2000). The effect of strategic alignment on the use of IS-based resources for competitive advantage. Journal of Strategic Information Systems, 9, 265-293. http://dx.doi.org/10.1016/S0963$8687(00) 00049-4$

Kearns, G.S., \& Lederer, A. (2001). Strategic IT Alignment: A Model for Competitive Advantage. Proceedings of the 22nd International Conference on Information Systems. New Orleans.

Kearns, G.S., \& Lederer, A.L. (2003). A resource-based view of strategic IT alignment: How knowledge sharing creates competitive advantage. Decision Sciences, 34 (1), 1-29. http://dx.doi.org/10.1111/15405915.02289

Keen, P.G.W. (1991). Shaping the Future: Business Design Through Information Technology. Cambridge: Harvard Business School Press.

Kempaiah, R. (2008). Analysis of performance impact and benchmarking strategic alignment maturity in Indian IT service industry. Obtained from ProQuest Dissertation \& Theses: Full Text (AAT 3317881).

Labovitz, G., \& Rosansky, V. (1997). The Power of Alignment: How Great Companies Stay Centered and Accomplish Extraordinary Things. New York: John Wiley \& Sons, Inc.

Lederer, A., \& Mendelow, A. (1989). Co-ordination of information systems plans with business plans. Journal of Management Information Systems, 6 (2), 5-19. http://dx.doi.org/10.1080/07421222.1989.11517854

Lee, D.M.S., Trauth, E., \& Farwell, D. (1995). Critical skills and knowledge requirements of is professionals: A joint academic/industry investigation. MIS Quarterly, 19(3), 313-340. http://dx.doi.org/10.2307/249598

Luftman, J.N. (1996). Competing in the Information Age: Practical Applications of the Strategic Alignment Model. New York: Oxford University Press.

Luftman, J.N. (2000). Assessing business-IT alignment maturity. Communications of the AIS, 4(14), 1-51.

Luftman, J., Papp, R., \& Brier, T. (1999). Enablers and inhibitors of business - IT alignment. Communications of the ACM, 1(11).

Masrek, M.N., \& Jusoff, K. (2009). The effect of information technology infrastructure flexibility on intranet effectiveness. Computer and Information Science, 2 (2), 57-67. http://dx.doi.org/10.5539/cis.v2n2p57 
McKay, D.T., \& Brockway, D.W. (1989). Building I/T infrastructure for the 1990s. Stage by Stage, 9(3), $1-11$.

Mendelson, H., \& Pillai, R.R. (1998). Clockspeed and informational response: Evidence from the information technology industry. Information Systems Research, 9(4), 415-433.

http://dx.doi.org/10.1287/isre.9.4.415

Nelson, R. (1991). Educational needs as perceived by is and end user personnel: a survey of knowledge and skill requirements. MIS Quarterly, 15(4), 503-525. http://dx.doi.org/10.2307/249454

Ness, L.R. (2005). Assessing the relationships among it flexibility, strategic alignment, and it effectiveness: study overview and findings. Journal of Information Technology Management, 16(2), 1-17.

Nunnally, J.C., \& Bernstein, I.H. (1994). Psychometric Theory. New York: McGraw-Hill.

Orozco, J., Tarhini, A., Masa'deh, R., \& Tarhini, T. (2015). A Framework of IS/Business Alignment Management Practices to Improve the Design of IT Governance Architectures. International Journal of Business and Management, 10(4), 1-12. http://dx.doi.org/10.5539/ijbm.v10n4p1

Paschke, J., Molla, A., \& Martin, B. (2008). The extent of IT-enabled organisational flexibility: An exploratory study among australian organisations. In 19th Australasian Conference on Information Systems. Christchurch.

Patten, K., Whitworth, B., Fjermestad, J., \& Mahinda, E. (2005). Leading IT flexibility: Anticipation, agility and adaptability. In Proceedings of the Eleventh Americas Conference on Information Systems. Omaha, NE, USA.

Plowman, B. (1998). Companies struggle to align business strategies, IT priorities. Available at http://www.csc.com/about/news stories/19981118 b.html (Accessed: June 1999).

Reich, B.H., \& Benbasat, I. (1996). Measuring the linkage between business and information technology objectives. MIS Quarterly, 20(1), 55-81. http://dx.doi.org/10.2307/249542

Reich, B.H., \& Benbasat, I. (2000). Factors that influence the social dimension of alignment between business and information tecnology objectives. [Research Article]. MIS Quarterly, 24(1), 81-113. http://dx.doi.org/10.2307/3250980

Roach, S.S. (1991). Services under siege: The restructuring imperative. Harvard Business Review, 39(2).

Rockart, J.F., \& Short, J.E. (1989). IT in the 1990s: Managing organizational interdependence. Sloan Management Review, 30(2), 7-17. 
Sabherwal, R., \& Chan, Y.E. (2001). Alignment between business and IS strategies: A study of prospectors, analyzers and defenders. Information Systems Research, 12(1), 11-33.

http://dx.doi.org/10.1287/isre.12.1.11.9714

Sari, N.T., Hidayanto, A.N., \& Handayani, P.W. (2012). Toward Catalog of Enterprise Resource Planning (ERP) Implementation Benefits for Measuring ERP Success. Journal of Human Resources Management Research, 2012, pp. 1-16. http://dx.doi.org/10.5171/2012.869362

Segars, A.H., Grover, V., \& Teng, J.T.C. (1998). Strategic information systems planning: planning system dimensions, internal coalignment, and implications for planning effectiveness. Decision Sciences, 29(2), 303-341. http://dx.doi.org/10.1111/j.1540-5915.1998.tb01579.x

Stone, M. (1974). Cross-validatory choice and assessment of statistical predictions. Journal of the Royal Statistical Society, 36(2), 111-133.

Tallon P.P., \& Kraemer, K.L. (2003). Using flexibility to enhance the alignment between information systems and business strategy: implications for it business value. Center for Research on Information Technology and Organizations (CRITO), University of California, Irvine. http://dx.doi.org/10.1080/07421222.2000.11518269

Tallon, P.P., Kraemer, K.L., \& Gurbaxani, V. (2000). Executives' Perceptions of the Business Value of Information Technology: A Process-Oriented Approach. Journal of Management Information Systems, 16(4), 145-173.

Tallon, P.P., \& Pinsonneault, A. (2011). Competing perspectives on the link between strategic information technology alignment and organizational agility: Insights from a mediation model. MIS Quarterly, 35(2), 463-486.

Tarhini, A., Ammar, H., Tarhini, T., \& Masa'deh, R. (2015). Analysis of the Critical Success Factors for Enterprise Resource Planning Implementation from Stakeholders' perspective: A Systematic Review. International Business Research, 8(4), 25-40. http://dx.doi.org/10.5539/ibr.v8n4p25

Teo, T., \& King, W. (1997). Assessing the impact of integrating business planning and IS planning. Information \& Management, 30(6), 309-321. http://dx.doi.org/10.1016/S0378-7206(96)01076-2

Urbach, N., \& Ahlemann, F. (2010). Structural equation modeling in information systems research using partial least squares. Journal of Information Technology Theory and Application, 11(2), 5-40. 
Weill, P. (1993). The Role and Value of Information Technology Infrastructure: Some Empirical Observations. In Banker, R., Kaufman, R., \& Mahood, M.A. (Eds.). Strategic Information Technology Management: Perspectives on Organizational Growth and Competitive Advantage. Idea Group Publishing, Middleton. 547-572.

Werts, C.E., Linn, R.L., \& Jöreskog, K.G. (1974). Intraclass reliability estimates: Testing structural assumptions. Educational and Psychological Measurement, 34, 25-33.

http://dx.doi.org/10.1177/001316447403400104

Wetzels, M., Odekerken-Schröder, G., \& van Oppen, C. (2009). Using PLS path modeling for assessing hierarchical construct models: Guidelines and empirical illustration. MIS Quarterly, 33(1), 177-195.

Wold, H. (1985). Partial least squares. Encyclopedia of Statistical Sciences, 6, 581-591.

Yayla, A.A., \& Hu, Q. (2012). The impact of IT-business strategic alignment on firm performance in a developing country setting: exploring moderating roles of environmental uncertainty and strategic orientation. European Journal of Information Systems, 21(4), 373-387. http://dx.doi.org/10.1057/ejis.2011.52

\section{Annex A. Questionnaire Items}

\begin{tabular}{|c|c|c|}
\hline Variable & Code & Indicator \\
\hline \multicolumn{3}{|r|}{ IT Infrastructure Flexibility } \\
\hline \multirow{5}{*}{ Connectivity } & $\mathrm{CNC1}$ & Our systems are flexible enough to integrate electronic link to external parties \\
\hline & $\mathrm{CNC} 2$ & Our company has a high degree of interconnectivity system \\
\hline & CNC3 & The entire remote office and mobile personnel can connect with headquarters \\
\hline & CNC4 & Our company establishes a mechanism to open systems network to improve connectivity \\
\hline & CNC5 & The company's database can be accessed through a number of different protocols \\
\hline \multirow{6}{*}{ Modularity } & MOD1 & Reusable software modules have been widely used in system development \\
\hline & MOD2 & Legacy system in the company does not hamper the development of new IT applications \\
\hline & MOD3 & $\begin{array}{l}\text { The functionality can be added easily to the core application in accordance with user } \\
\text { demand }\end{array}$ \\
\hline & MOD4 & Rules and data relationships are not hard set forth in the application \\
\hline & MOD5 & $\begin{array}{l}\text { IT personnel utilizing modular object-oriented programming and other tools to develop } \\
\text { software }\end{array}$ \\
\hline & MOD6 & Data can be accessed by anyone (authorized) in real time \\
\hline \multirow{4}{*}{ Compatibility } & CMP1 & Software can be easily transported and used cross-platform \\
\hline & CMP2 & Our company uses extensively middleware to integrate core enterprise applications \\
\hline & CMP3 & $\begin{array}{l}\text { Our company offers a wide range of interfaces or entry points (eg, web access, EDI) to } \\
\text { external users }\end{array}$ \\
\hline & CMP4 & Our company provides various types of information to end users \\
\hline
\end{tabular}




\begin{tabular}{|c|c|c|}
\hline Variable & Code & Indicator \\
\hline \multirow{7}{*}{$\begin{array}{l}\text { Adaptability of IT } \\
\text { Personnel }\end{array}$} & ITP1 & $\begin{array}{l}\text { IT personnel are able to interpret business issues and develop appropriate technical } \\
\text { solutions }\end{array}$ \\
\hline & ITP2 & IT personnel capable of planning and work collectively \\
\hline & ITP3 & IT personnel have knowledge of business functions \\
\hline & ITP4 & $\begin{array}{l}\text { IT personnel trained in cross-unit (cross-training) to support IT services outside their } \\
\text { specialties }\end{array}$ \\
\hline & ITP5 & IT personnel have knowledge about the key factors for organization success \\
\hline & ITP6 & IT personnel have knowledge about the various technologies and tools \\
\hline & ITP7 & IT personnel are encouraged to learn new technologies \\
\hline \multicolumn{3}{|r|}{ Business-IT Alignment (Luftman Model) } \\
\hline \multirow{6}{*}{ Communication } & COM1 & $\begin{array}{l}\text { How do you assess the understanding of the IT unit of the company's business } \\
\text { environment, for example: customers, competitors, processes, partner, etc.? }\end{array}$ \\
\hline & $\mathrm{COM} 2$ & $\begin{array}{l}\text { How do you assess the understanding of the business units of the company's IT } \\
\text { environment, such as: IT capabilities now and in the future, systems, services, etc.? }\end{array}$ \\
\hline & COM3 & What is the process of learning in today's organizations? \\
\hline & COM4 & What is the nature of communication between IT and the business today? \\
\hline & COM5 & $\begin{array}{l}\text { How is the knowledge sharing process related problems, opportunities, tasks, roles, } \\
\text { priorities, etc. which occurred in the company? }\end{array}$ \\
\hline & COM6 & $\begin{array}{l}\text { Is there any use of staff liaison (liaison) as Business Analyst for example, between IT with } \\
\text { the business? If there is, how effective the use of such liaison? }\end{array}$ \\
\hline \multirow{7}{*}{$\begin{array}{l}\text { Value } \\
\text { measurement }\end{array}$} & VAL1 & In assessing the contribution of IT to the business, what processes and parameters are used? \\
\hline & VAL2 & What are the parameters used in assessing the competence of the business? \\
\hline & VAL3 & $\begin{array}{l}\text { Are the value measurements of of IT investments and business already integrated? How are } \\
\text { the value measurements performed and what parameters are used? }\end{array}$ \\
\hline & VAL4 & How SLA practices applied in the company? \\
\hline & VAL5 & How are benchmarking practices applied in the company? \\
\hline & VAL6 & How are IT investments assessed and reviewed? Is there a formal process? \\
\hline & VAL7 & $\begin{array}{l}\text { How are continuous improvement processes performed? Is there any measurement of the } \\
\text { effectiveness of such processes? }\end{array}$ \\
\hline \multirow{7}{*}{ Governance } & GOV1 & How is the IT unit's participation in business strategic planning? \\
\hline & GOV2 & How is the business unit's participation in IT strategic planning? \\
\hline & GOV3 & How is the reporting process performed in the IT department? \\
\hline & GOV4 & How is the budget control of the IT function performed? \\
\hline & GOV5 & What parameters are used in determining the decision to invest in IT? \\
\hline & GOV6 & How is the role of the Steering Committee within the company? \\
\hline & GOV7 & How is the process of determining priorities for IT projects? \\
\hline \multirow{6}{*}{ Partnership } & PRT1 & What are the perceptions of the business unit to IT? \\
\hline & PRT2 & How is the role of IT in business strategic planning? \\
\hline & PRT3 & How risk management is performed by the business units and IT to IT projects? \\
\hline & PRT4 & $\begin{array}{l}\text { How relationship management is performed to foster the relationship between IT and the } \\
\text { business? }\end{array}$ \\
\hline & PRT5 & How the relationships and trust are built between the IT and business unit? \\
\hline & PRT6 & How does the business support IT initiatives? \\
\hline \multirow{5}{*}{$\begin{array}{l}\text { Scope and } \\
\text { Architecture }\end{array}$} & ARC1 & What is the main role of IT systems in the enterprise? \\
\hline & ARC2 & How to standardize the IT systems? \\
\hline & ARC3 & How is the integration of IT infrastructure components performed? \\
\hline & ARC4 & How to guarantee the transparency when there are changes related to business or IT? \\
\hline & ARC5 & How flexible IT infrastructure to market changes? \\
\hline
\end{tabular}




\begin{tabular}{|l|l|l|}
\hline \multicolumn{1}{|c|}{ Variable } & \multicolumn{1}{|c|}{ Code } & \multicolumn{1}{c|}{ Indicator } \\
\hline \multirow{4}{*}{ Skills } & SKI1 & How does the company support to innovation and entrepreneurship? \\
\cline { 2 - 3 } & SKI2 & Who is entitled to take decisions related to IT personnel? \\
\cline { 2 - 3 } SKI3 & $\begin{array}{l}\text { What is the orientation of the company's management style today? Command, consensus, } \\
\text { results, profit, or relationships? }\end{array}$ \\
\cline { 2 - 3 } & SKI4 & How is the company's readiness in facing the internal and external changes? \\
\cline { 2 - 3 } & SKI5 & $\begin{array}{l}\text { Are there opportunities for career development across units? Who is entitled to get the } \\
\text { chance? }\end{array}$ \\
\cline { 2 - 4 } & SKI6 & Is there a chance to get a cross unit training? Who is entitled to get the chance? \\
\cline { 2 - 3 } & SKI7 & How is the interaction between IT personnel with the business? \\
\cline { 2 - 3 } & SKI8 & How are employee recruitment and retention performed? \\
\hline
\end{tabular}

Journal of Industrial Engineering and Management, 2016 (www.jiem.org)

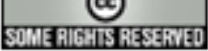

Article's contents are provided on an Attribution-Non Commercial 3.0 Creative commons license. Readers are allowed to copy, distribute and communicate article's contents, provided the author's and Journal of Industrial Engineering and Management's names are included. It must not be used for commercial purposes. To see the complete license contents, please visit http://creativecommons.org/licenses/by-nc/3.0/. 